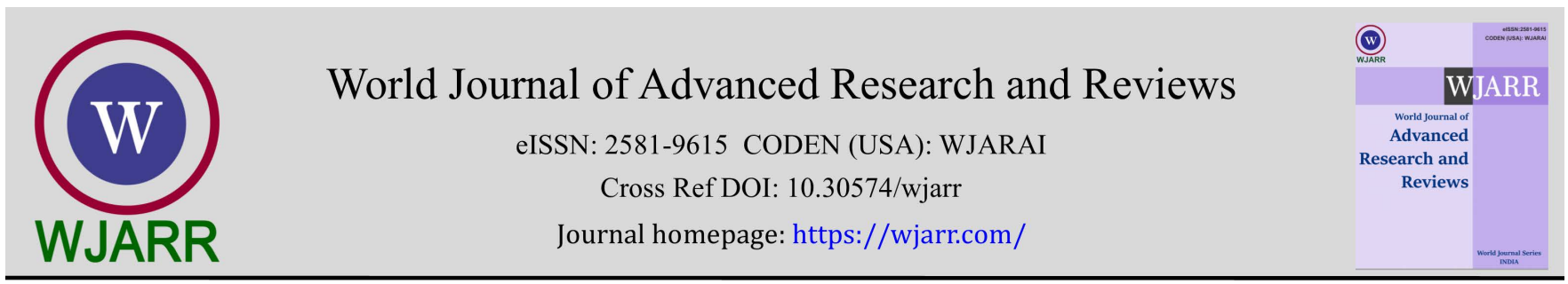

(REVIEW ARTICLE)

\title{
Antimycotic systems of bifidobacteria
}

\author{
Vladimir Mikhailovich Lakhtin *, Mikhail Vladimirovich Lakhtin, Valeriy Yurjevich Davydkin, Alexandra \\ Vadimovna Melikhova, Igor Yurjevich Davydkin and Olga Gennadyevna Zhilenkova
}

Department of Medical Biotechnology, G.N. Gabrichevsky Research Institute for Epidemiology and Microbiology, Russia 125212, Moscow, Admiral Makarov Street, 10.

World Journal of Advanced Research and Reviews, 2021, 09(01), 069-074

Publication history: Received on 22 December 2020; revised on 02 January 2021; accepted on 04 January 2021

Article DOI: https://doi.org/10.30574/wjarr.2021.9.1.0496

\begin{abstract}
Based on own data, the basis positions concerning probiotic bifidobacteria as producers of adaptable and controlled network of functionally coupled antimycotics of the recognition type (lectin and lectin-like type) were described. Such antimycotics act as an organized ordered system of metabolomebiotics which are distinct from the classical antibiotics, acting with other (expanded) mechanisms resulting in increase of resistance of the organism protective network. Bifidobacterial antimycotics are represented by probiotc lectin and postbiotic systems of promised prophylactic and therapeutic significance in future.
\end{abstract}

Keywords: Bifidobacteria; Probiotics; Postbiotics; Antimycotics; Lectin systems; Glycoconjugates

\section{Introduction}

Bifidobacteria (genus Bifidobacterium, family Actinomycetaceae, order Actinomicetales, class Actinobacteria) are characterized by taxonomic proximity with not only lactobacilli and symbiotic corynebacteria, but also with fungi which are known possess high level communicative and metabolic potential in biotopes. Bifidobacteria reveal significant adaptive morphological and functional polymorphism in both during their live circle and depending on changes in biotope surroundings. There are a number of evolutionary and involutionary (visible) examples of such cases. Bifidobacterial polymorphism is revealed depending on: a) mucosal organ current status (examples can include cases of mother metabolome status before, during or after gestation periods; characterization of the newborn, infant and child interactomes), b) environment current conditions (cultural media, personal biotope different biorhythms). Programmed high adaptation of bifidobacteria is realized through diversity of their behavior within mucosal biotopes of the organism open cavities (including a number of cases providing bifidobacterial domination in mucosal microbiocenosis taxonomic composition and inter-niche hierarchical relationships among microbes). Bifidobacteria reveal visible antagonism in respect of staphylococci and yeast-like fungi that indicates capability of bifidobacteria to produce the network of antibiotics-like agents.

The aim of this review is to accent potential of bifidobacteria as sources of serial system antimycotics (including complex and individual synergistic combinations of prolongated action) against opportunistic combinations of fungi and Gram positive bacteria (based on own publications [1-35]).

Lectins are related to protein/ (oligo) peptide molecules and their complexes which are capable to recognize and reversibly bind carbohydrates and carbohydrate moiety of glycoconjugates (GC). Lectins of the cultural probiotic strains of lactobacilli and bifidobacteria (from the healthy adult donor intestines) were isolated and characterized by us [1-19,

\footnotetext{
${ }^{*}$ Corresponding author: Lakhtin Vladimir

Department of Medical Biotechnology, G.N. Gabrichevsky Research Institute for Epidemiology and Microbiology, Russia 125212, Moscow, Admiral Makarov Street, 10.

Copyright (C) 2021 Author(s) retain the copyright of this article. This article is published under the terms of the Creative Commons Attribution Liscense 4.0.
} 
21-25]. Probiotic lectins studied were from the Russian multi-strain lactobacillar probiotic - Acilact (its properties as the sum of three ingredient strains) and bifidobacterial mixture of consortium type $[1,2,5,7,19]$.

Lectin preparations represent probiotic lectin systems (PLS as the associates of the detergent- and temperaturesensitive components of $>27 \mathrm{kDa}$, anionic/acidic and cationic/alkaline, lactobacillar and bifidobacterial: aLL, cLL, aLB and cLB). They reveal key properties and activities of indigenous strains and consortia of mucus within mucosal organs of the intestinal open cavities. PLS possess intra-system synergistic action. PLS and postbiotics as key sources of antimycotics-like systems

According to our data, PLS (major and minor sub-systems) reveal a lot of examples of antibiotic-like properties. PLS are able to convert into postbiotic systems (PS) retaining the most important features - the ability to bind GC. PS, in their turn, prevent pathological processes in direction of improving health of patients.

Consideration of postbiotics (conversed PLS products, combinative compositions of PS) proved to be a convenient instrumental approach to predict assessment of bifidobacterial potential (mono- and multi-strain combinations and consortia) as sources of varying antimicotic-like agents (molecules and their supramolecular associates or assemblies) [20, 26-35].

Advantages of this approach are the following: a) revealing new properties of PLS compared to low molecular mass postbiotics; b) consideration of PLS within recognizing GC network with action in knots of cascade reaction branches; c) possibility to order PLS in direction of potential therapeutic postbiotics.

\subsection{New properties of PLS compared to low molecular mass postbiotics}

PLS (major and minor visible asymmetric subsystems) imitate main activities of probiotic cells and realize these activities ahead and independently of cells. They act independently on the presence of antibiotics and are not influenced with other cell limiting environmental factors. They show synergy with other types of antimicrobial agents and food and cold stress factors. In sub-cytoagglutinating doses PLS realize lectin-coupled biological and physiological add-on activities as mini-cascades. Settings of the further reaction cascades in the metabolomebiotic [12] and metabolic axes [29] network can be predicted.

PLS (strongly acidic [around pI 4], slightly acidic [pI 5-6] and alkaline [pI 7-8 and higher]) reveal synergism in antimycotic actions. Examples of synergism include: LB and LL; PLS and phytolectins, PLS and classical antimycotics of azole type; PLS and factors of food and/or cold stress. Upon interaction of PLS with molecules and receptors, the formed contacts contribute into modification of previous type of specificity or switching specificity to a new GC type in cases of PLS components. As a result, a spectrum of targets for antimycotics is expanded, and effectiveness of their action is increased. In such conditions of mucosal biotope surrounding, the targetting PLS subsystems involving new effector complexes of LB and LL is improved. Complexing such antagonistic constituents involves nature parameters of opportunistic fungi (fungal components as signals and current phenotype memory) that allows orientation and action of PLS in respect of available fungal pathogens and their associates as mini-biofilms) in surroundings using direct or indirect (through a network) influence.

\subsection{PLS as a network including protein/ (oligo) peptide antimycotics - metabolomebiotics}

Postbiotics (on example of PLS) are represented as infra-structural (major visible protein/peptide containing ingredients) and signal (minor visible ingredients) components or major and minor sub-system components in complexes with or without GC. PLS act according to the following general rules of a network of relationships between PLS and GC: "Any component of PLS - A set of GC targets ranged in availability and affinity to the PLS component", "One type of GC target-A set of PLS components (GC-dependent PLS subsystem) ranged in availability and affinity to the selected type of GC". Interaction of PLS with metabolite or cell target results in supra-molecular and (inter)cellular complexes possessing additional directed sites for further "PLS — GC recognition and binding" within contacts. The latter support idea that the formed complexes represent compositions possessing programmed modified or new (switched) directed specificity to GC.

Among obtained results there are main groups to be underlined as the following ones.

i. Sensoric properties of specie and sub-specie selectivity (communicative properties that can be used in antagonistic and competitive reactions) towards bifidobacteria at the level of postbiotic PLS targeted against fungi were established. Antagonism and antimycotic activity of LB in respect of Candida species were synergistically completed in the presence of additional LL action. 
ii. PLS (including products of dissociation of complexesand/or other type of conversion) behave like "mild" system GC-recognizing antimycotics of a new type (adaptable, system, cascade, redirect, involving target constituents) with early and deferred/network antifungal/antibacterial actions (according to different synergistic mechanisms) against Candida species of all groups I-III of epidemiological significance: a) throuph conversions in suspensions (using surrounding fungal hydrolases triggering metabolic suicide of Candida group I including $C$. albicans and $C$. tropicalis), b) throuph early biorhythmic functional separation of suspension forms of Candida groups I (on example of $C$. tropicalis) and III (C. krusei), c) throuph assembling biofilms (BF) on surfaces or inter-phases (in cases of $C$. albicans and $S$. aureus), d) throuph neutralization of enzymatic virulent factors of Candida group II (C. glabrata), e) throuph prolonged biocontrol of bactericideness and fungicideness within common symbiotic microbial areas (for example, against the background of a joint territory restriction of mixed BF including C. albicans together with aspergilli).

iii. Strategies against BF-forming chronic infections microorganisms involving possibilities of the PLS-coupled simultaneous lysis of pathogen massifs and BF internally (strategy "Target-in-Target") and directed from the external borders of BF (strategies of rational combination of probiotic attacks and antimicrobial preparations in respect of the whole $\mathrm{BF}$ ) are especially perspective ones.

Thus, in respect of combinations "Candida+Staphylococcus" it is possible to apply PLS in the folowing directions: a) against Candida and other yeast like fungi: aLB (visible action on peripheral regions of BF) $>$ aLL (visible action on internal regions of $\mathrm{BF}$ possessing increased visible protection); aLB+aLL (residual multi-island/center BF after probiotic prolonged attack); LB+LL+metabolite-cell probiotics (cell constituent as providing depth and reliability of resistance of microbiocenose probiotic compartment; possibility of maneuver throuph simplified cell amplification in the presence of LB and LL; potential of additional producing PLS); b) against staphylococci: aLL (actions that regionally differ from those of aLB within BF)> aLB (visible actions in peripheral regions of BF; actions that differ from the area and nature of those of aLL; peripheral completely lyzed BF fragments); aLL+aLB (synergism as both territorial and by the nature of the action); LL+LB+probiotics (the system revealing maximal prolonged synergism). cPLS (cLB and/or CLL) reveal deferred anti-Candida action (against C. albicans [later action compared to that of aPLS]; action against preferential internal areas of BF that directly capture the central - mostly protected region of the fungal pathogen massif and BF). Action of cPLS is supported by cofunctioning of both cLB and cLL with endogenic polymeric biosurfactants (for example providing the remote delivery of cPLS and peptides).

Aforementioned data justify bifidobacteria as perspective sources of adaptable functionally coupled in time and space GC-recognizing system antimycotics of a new complicated type. Such antimycotic systems are one of key participants involved into organization of the whole synergistic metabolite-cell anti-(fungal pathogens) network of inter-organ/ inter-issue/ inter-cell-axes connecting the mucosa and controlling the communication of the mucosal organ with other organs and tissues and targeting GC all over the body. Such a network assumes actions (synergistic participation and contribution) of other body protective systems. It involves functioning pre-, pro-, syn-, immuno-, post-, enzyme-bioitics, ingredients of functional food and vaccines.

According to the data described above and our conceptual proposals, it is possible new additional explanation and disclosure of the nature, for example, of the fact that in case of infant microbiocenoses there is a pronounced large-scale substitution of fungi and bacteria with minimal (in specie composition) bifidobacterial consortia (consortia possessing high signal and adaptive/ communicative potential in recognition of target sets). The latter allows successfully implemented monitoring of the local microbiota in mediating the dominant communications (in connection with the functional redistribution - the partial/ temporary interception of fungal supervising functions) between microbiocenosis and mucosal organ infra-structure.

The use of consortium nature preparations of LB and LL (that are biocompatible and mimic the properties of consortium cells) as managed and directed sources of ordered/ serial/ system antibiotic/ antimycotic-like compounds and substances against combinations of pathogenic fungi and Gram positive bacteria (on examples of $C$. albicans and $S$. aureus) is the "number 1 " of promised prospects. This can be important for increasing effectiveness of the fight (as well as prediction of success) against BF-associated staphylococcoses (preferential action of system constituents of LL) and staphylococcal candidoses (preferential action of system constituents of LB, LB, LL, PLS together with postbiotics and cell type probiotics). It is possible prognostic choice of mixed inter-specie (bifidobacterial) and inter-genus (bifidobacteria and lactobacilli) symbiotic associative consortia possessing mostly adequate action against pathogens (fungal, bacterial, fungal+bacterial) using consortium constructed combinative antimycotic system to act in a biotope of interest. 


\section{Conclusion}

Aforementioned data indicate and predict further expanded applications of LPS and PS as antibiotic-/antimycotic-like agents in future. Such synergistically acting agents will help in development of new probiotic/postbiotic metabolic and metabolite-cell systems against groups of microbial and viral infections, pathologies and diseases. Synergistical both PLS and PS in combinations with effector GC, antibiotics, other antimicrobial and antiviral (also in connection with the presence of Covid-19 in organism) agents and factors are of especial and preferential interest to be investigated.

\section{Compliance with ethical standards}

\section{Acknowledgments}

The authors are grateful to the heads of the laboratories of the department of Medical Biotechnology of G.N. Gabrichevsky Research Institute for Epidemiology and Microbiology for making available their facilities for usage and support. Special thanks are expanded to those who contributed to the research and writing of this article.

\section{Disclosure of conflict of interest}

Authors declare the absence of conflict of interest statement.

\section{References}

[1] Lakhtin VM, Lakhtin MV, Pospelova VV, Shenderov BA. Lactobacilli and bifidobacteria lectins as possible signal molecules regulating intra- and inter-population bacteria-bacteria and host-bacteria relationships. Part I. Methods of bacterial lectin isolation, physicochemical characterization and some biological activity investigation. Microbial Ecology Health Disease. 2006; 18(1): 55-60.

[2] Lakhtin VM, Lakhtin MV, Pospelova VV, Shenderov BA. Lectins of lactobacilli and bifidobacteria. II. Probiotic lectins of lactobacilli and bifidobacteria as possible signal molecules regulating inter- and intra-population relationships between bacteria and between bacteria and the host. Microbial Ecolology Health Disease. 2007; 19(3): 153-157.

[3] Lakhtin VM, Lakhtin MV, Korsun VF, Shenderov BA. Mutual potential of probiotic microorganisms and fungi in conditions of organization and functioning of the model eukaryotic cell biofilms - for further using phytocompositions in clinical practice. Practical Phytotherapy (Moscow) [Prakticheskaya fitoterapiya (Moskva)]. 2008; 2: 11-17 (in Russian)

[4] Lakhtin MV, Lakhtin VM, Alyoshkin VA, Afanasyev SS, Pozhalostina LV, Pospelova VV, Korsun VF. Antifungal potential of lectin probiotic and phyto-preparations: Types, mechanisms and factors of action against human pathogenic fungi. Practical Phytotherapy (Moscow) [Prakticheskaya fitoterapiya (Moskva)]. 2009; 4: 17-25 (in Russian)

[5] Lakhtin M, Alyoshkin V, Lakhtin V, Afanayev S, Pozhalostina L, Pospelova V. Probiotic lactobacillus and bifidobacterial lectins against Candida albicans and Staphylococcus aureus clinical strains: New class of pathogen biofilm destructors. Probiotics and Antimicrobial Proteins. 2010; 2(3): 186-196.

[6] Lakhtin MV, Lakhtin VM, Alyoshkin VA, Afanasyev SS, Pozhalostina LV, Pospelova VV, Korsun VF. Phytolectins and probiotic lectins - synergistic anti-pathogens. Practical Phytotherapy (Moscow) [Prakticheskaya fitoterapiya (Moskva)]. 2010; 1: 5 - 11 (in Russian)

[7] Lakhtin M, Lakhtin V, Aleshkin A, Aleshkin A, Afanasiev S, Aleshkin V. Lectin systems imitating probiotics: Potential for biotechnology and medical microbiology. In: "Probiotics 2012", E.C. Rigobelo (ed.). New York, InTech. 2012: 417-432.

[8] Lakhtin MV, Afanasyev SS, Lakhtin VM, Bajrakova AL, Aleshkin VA. Lectins of human probiotic bacteria prevent distribution of mixed biofilms "Candida+Aspergillus"of human urogenital biotope mycobiota. Advances in Medical Mycology (Moscow) [Uspehi meditsinskoy mikologii (Moskva)]. 2014; 12: 34-37 (in Russian)

[9] Lakhtin MV, Lakhtin VM, Afanasyev SS, Karaulov AV, Korsun VF, Alyoshkin VA, Afanasyev MS. (2015). Fungal biofims: Decisive role of an initiator of assembly in prolongation of the resistance and degradation. Advances in Medical Mycology (Moscow) [Uspehi meditsinskoy mikologii (Moskva)], 14: 196-198 (in Russian) 
[10] Lakhtin MV, Lakhtin VM, Afanasyev SS, Karaulov AV, Bajrakova AL, Alyoshkin VA, Afanasyev MS. Synbiotope basis against fungal-bacteria; pathogens: New anti-Candida strategies. Advances in Medical Mycology (Moscow) [Uspehi meditsinskoy mikologii (Moskva)]. 2016; 15: 261-264 (in Russian)

[11] Lakhtin MV, Lakhtin VM, Afanasiev SS, Aleshkin VA. Applied prospects of probiotic lectin systems of the human symbiotic microbiocenosis strains and consortia. In: Applied and Fundamental Studies: Proceedings of the 10th International Academic Conference. November 21-22, 2016, St. Louis, Missuri, USA. Publishing House "Science and Innovation Center". 2016: 5-15.

[12] Lakhtin VM, Lakhtin MV, Afanasyev SS, Alyoshkin VA. Symbiotic Lectins - Metabolomebiotics and Carriers of Metabiotics. Gastroenterology of Saint Petersburg [Gastroenterologiya Sankt-Peterburga]. 2016; No 3-4: page M15a (in Russian)

[13] Lakhtin MV, Lakhtin VM, Bajrakova AL, Afanasyev SS, Alyoshkin VA, Korsun VF. Lectin systems in screening and constructing preparations influencing niches of pathogens. Practical Phytotherapy (Moscow) [Prakticheskaya fitoterapiya (Moskva)]. 2017; 1: 13-18 (in Russian)

[14] Lakhtin MV, Lakhtin VM, Afanasiev SS, Aleshkin VA. Consortium and strain probiotic lectin systems of mucosal immunity against mucosal infections and tumors: Potential of pro/synbiotics influence on microbiocenoses. Problems of Scientific Thought (Dnepr, Ukraine) [Problemy nauchnoy misli (Dnepr)]. 2018; 7(12): 25-44 (in Russian)

[15] Lakhtin MV, Lakhtin VM, Afanasiev SS, Bayrakova AL, Aleshkin VA, Afanasiev MS. Candida markers of urogenital biotope diseases: Reactivity to lectins of probiotics. Acta Biomedica Scientifica. 2018; 3(1): $49-53$ (in Russian)

[16] Lakhtin MV, Lakhtin VM. Probiotic lectin systems: Prospects of mucosal organ health biocontrol. Advances in Medical Mycology (Moscow) [Uspehi meditsinskoy mikologii (Moskva)]. 2019; 20: 24-29 (in Russian)

[17] Lakhtin MV, Lakhtin VM. Antifungal basis lectin supersystem of human. Advances in Medical Mycology (Moscow) [Uspehi meditsinskoy mikologii (Moskva)]. 2019; 20: 30-35 (in Russian)

[18] Lakhtin MV, Lakhtin VM, Afanasiev SS, Bajrakova AL, Aleshkin VA, Afanasiev MS, Korsun VF. Prospects of probiotic lectins (recognizing and binding glycoconjugates) in reproductive medicine and neonatology: Increasing mucosal immunity. Obstetics and Gynecology (Moscow) [Akusherstvo i ginekologiya (Moskva)]. 2019; 4 (Supplement): 39 (in Russian)

[19] Lakhtin MV, Lakhtin VM, Aleshkin VA, Afanasiev SS. Metabolite Multiprobiotic Formulas for Microbial Health. In: Oral Health by Using Probiotic Products, Razzagh Mahmoudi (Editor). London, United Kingdom, InTech. 2019: 71-91.

[20] Davydkin VYu, Davydkin IYu, Melikhova AV, Lakhtin VM, Klimova EV. Method of dispersing the culture liquid of bifidobacteria / Patent RU 2731063 C1, Registered (in Russian)

[21] Lakhtin MV, Lakhtin VM, Afanasiev SS, Bajrakova AL, Afanasiev MS, Aleshkin VA. Mucosal Candida species microecology, sensitivity to antifungals, antifungal strategies considering probiotic pressure. News of Science and Education. 2019; 5(3): 3-21.

[22] Lakhtin VM, Lakhtin MV, Afanasiev SS, Davydkin VYu, Aleshkin VA. Communications between proteins and glycoconjugates in organism infected with Covid. World Journal of Pharmaceutical Research (WJPR). 2021; 10(1).

[23] Lakhtin MV, Lakhtin VM, Aleshkin VA. The Role and Prospects of Lectins of Indigenous Mucosal Microflora in Regulation of Mucosal Microbiocenoses of Open Cavities of the Body. Problems of Scientific Thought (Dnepr, Ukraine) [Problemy nauchnoy misli (Dnepr)]. 2020; 4(1): 6-23 (in Russian)

[24] Lakhtin MV, Lakhtin VM, Aleshkin VA. The Role of Lectins of Microbes of Indigenic Mucus Microflora in Regulation of Mucosal Microbiocenoses of the Organism Open Cavities and Immuno-Biological Supervision. Ural Scientific Bulletin (Uralsk, Kazakhstan) [Uralskiy nauchniy vestnik (Uralsk, Kazahstan)]. 2020; 4(2): 9-41 (in Russian)

[25] Lakhtin MV, Lakhtin VM, Aleshkin VA, Afanasiev SS. The Recognizing Glycoconjugates Proteins of the Human Mucosal Immunity: Lectin Systems of Probiotic Compartment of Mucosal Biotopes of Open Cavities of Organism. Pharmacy (Saint Petersburg) [Farmatsiya (Sankt Peterburg)]. 2020; 69(1): 10-16 (in Russian)

[26] Lakhtin MV, Lakhtin VM, Bajrakova AL, Davydkin VYu, Davydkin IYu, Afanasiev MS, Afanasiev SS, Aleshkin VA. Probiotic Recognition Factors Influencing Microbiocenosis Microecology: Prospects for Medical Biotechnology. Pridneprovskiy Scientific Bulletin [Pridneprovsky nauchny vestnik (Dnepropetrovsk)]. 2020; 3(4): 3-19. 
[27] Lakhtin MV, Lakhtin VM, Davydkin IYu, Davydkin VYu, Mishin AA, Aleshkin VA. Probiotic bacteria with lectins of support of health in strategies of medical biotechnology, prophylaxis and therapy. News of Science and Education. 2020: 4(4): 9-18 (in Russian)

[28] Lakhtin MV, Lakhtin VM, Davydkin IYu, Melikhova AV, Davydkin VYu. Approaches to study therapeutic postbiotics. Ural Scientific Bulletin (Uralsk, Kazakhstan) [Uralskiy nauchniy vestnik (Uralsk, Kazahstan)]. 2020; 3(5): 3-15 (in Russian)

[29] Lakhtin MV, Lakhtin VM, Davydkin VYu, Melikhova AV, Davydkin IYu, Aleshkin VA. Postbiotics against infections, diseases and other pathologies. Problems of Scientific Thought (Dnepr, Ukraine) [Problemy nauchnoy misli (Dnepr)]. 2020; 3(7): 3-21 (in Russian)

[30] Lakhtin VM, Lakhtin MV, Davydkin VYu. Bifidobacteria - sources of antimycotic systems // Proceedings of the International Conference "Process Management and Scientific Developments" (Peking, China, August 5, 2020). Scientific publishing house "Infinity". 2020; 1: 120-128.

[31] Lakhtin MV, Lakhtin VM, Davydkin VYu. Systems recognizing glycoconjugates in medical biotechnbology. Problems of Scientific Thought (Dnepr, Ukraine) [Problemy nauchnoy misli (Dnepr)]. 2020; 3(6): 15-35 (in Russian)

[32] Lakhtin VM, Lakhtin MV, Davydkin VYu, Melikhova AV, Davydkin IYu. Relationships between probiotic lectins and postbiotics. World Journal of Advanced Research Reviews (WJARR). 2020; 7(1): 142-148.

[33] Lakhtin VM, Lakhtin MV, Davydkin VYu, Melikhova AV, Davydkin IYu. Pathways from probiotic lectins to therapeutic postbiotics. Problems of Scientific Thought (Dnepr, Ukraine) [Problemy nauchnoy misli (Dnepr)]. 2020; 3(6): 3-14 (in Russian)

[34] Lakhtin VM, Lakhtin MV, Davydkin VYu, Melikhova AV, Davydkin IYu. Mixed associates and biofilms in connection with pathologies in mucosal biotopes: Approaches, progress and prospects for medical biotechnologies // Science. Education. Practice (SEP): proceedings of the International University Science Forum (Canada, Toronto), November 11, 2020. - Infinity Publishing. 2020; 150-156.

[35] Lakhtin VM, Lakhtin MV, Davydkin VYu, Melikhova AV, Davydkin IYu, Zhilenkova OG. Postbiotic and other protective molecules recognizing and binding glycoconjugates in mucosal organs. American Scientific Journal. 2020; 43(1): 4-12. 